\title{
And now, for today
}

The breeze of thought,

Blows through home,

Vague, familiar,

On a ledge over the ocean,

Beating waves,

And twisting pirogues,

Oh to be there and feel taunting life.

Or dappled sun on fields of grass,

Should I recline,

Stretch my back,

Wait till flowers close,

Catch the whisper,

Stay, just here,

In the quieting room?

The starry beckon,

My name,

That I cannot recall,

A vast, dark space,

With twinkling, grinning,

Promise,

Of family past.

Or I could bury my soles,

In dunes,

Flop by the clock,

In time,

For library musk,

And fireflies.

The grand old dance,

The weaving steps,

Was it step-step step, or

One, two, three?

Under crystal lights,

Maybe I'll twirl the floor again,

Feet light as I pass and reach,

For canapes.

Or perhaps I'll stay,

Under blanket warmth,

Carpet underfoot,

And stop, just stop,

The choices, caged,

That once resounded,

Now that all is quieting.

Rajendra Shepherd

Correspondence to Rajendra Shepherd, Centre for Medical Sciences Education (CMSE), Eric Williams Medical Sciences Complex, Champs Fleur, Trinidad and Tobago, West Indies; rajendrashepherd@hotmail.com

Competing interests None declared.

Provenance and peer review Not commissioned; internally peer reviewed.

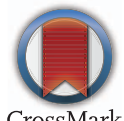

To cite Shepherd R. Med Humanit 2017;43:138.

Published Online First 2 March 2017

Med Humanit 2017;43:138. doi:10.1136/medhum-2017-011196 